\title{
Linking ecological debt and ecologically unequal exchange: stocks, flows, and unequal sink appropriation
}

\author{
Rikard Warlenius $^{1}$ \\ Lund University, Sweden
}

\begin{abstract}
Ecological debt is usually conceptualized as the accumulated result of different kinds of uneven flows of natural resources and waste, but these flows are seldom referred to as ecologically unequal exchange. Ecologically unequal exchange, on the other hand, is usually defined as different flows of resources and waste, but the accumulated results of these flows are seldom referred to as ecological debt. In this article, influential definitions and conceptualizations of ecological debt and ecologically unequal exchange are compared and the notions linked together analytically with a stock-flow perspective. A particular challenge is presented by emissions of substances that have global consequences, most importantly carbon dioxide and other greenhouse gases. They form part of ecologically unequal exchange, but what is unequal is not the exchange of resources or energy, but the appropriation of the sinks that absorb these substances. New concepts, unequal sink appropriation and the more specific carbon sink appropriation are proposed as a way of highlighting this distinction.
\end{abstract}

Key words: ecological debt, ecologically unequal exchange, unequal sink appropriation, carbon sink appropriation

\section{Résumé}

La dette écologique est généralement conceptualisée comme le résultat cumulé des différents types de flux inégale des ressources naturelles et des déchets, mais ces flux sont rarement appelé «échange écologiquement inégal». L'échange ecologiquement inégal, d'autre part, est généralement définie comme différents flux de ressources et des déchets, mais les résultats cumulés de ces flux sont rarement appelés «dette écologique». Dans cet article, les définitions et les conceptualisations des deux termes sont compares, et les notions liées à une perspective stock-flux. Un défi particulier est les émissions de substances qui ont des conséquences mondiales, surtout le dioxyde de carbone et d'autres gaz à effet de serre. Ils font partie de l'échange écologiquement inégal, mais ce qui est inégale est pas l'échange de ressources ou de l'énergie, mais l'appropriation des puits ('sinks') qui absorbent ces substances. De nouveaux concepts, «appropriation des puits inégal» et «appropriation de puits de carbone» sont proposées comme un moyen de mettre en évidence cette distinction.

Mots clés: dette écologique, échange écologiquement inégal, appropriation des puits inégal, l'appropriation des puits de carbone

\section{Resumen}

Se entiende habitualmente por deuda ecológica el resultado acumulado de distintos flujos desiguales de recursos naturales y de residuos aunque esos flujos no se siempre se describan como "comercio ecológicamente desigual." Por otro lado, se llama comercio o intercambio ecológicamente desigual a los distintos flujos de recursos y residuos aunque a los resultados acumulados de tales flujos no se le llame "deuda ecológica". En este artículo, consideramos y comparamos diversas definiciones y conceptualizaciones influyentes de la deuda ecológica y del comercio ecológicamente desigual, y ambas nociones quedan vinculadas mediante un análisis de stocks y flujos. Un desafío conceptual está en las emisiones de sustancias que tienen efectos globales, especialmente el dióxido de carbono y otros gases con efecto invernadero.

\footnotetext{
1 Rikard Warlenius, PhD student, Human Ecology Division, Lund University, Sweden. Email: rikard.warlenius "at"hek.lu.se. This is the third article in Alf Hornborg and Joan Martinez-Alier (eds.) 2016. "Ecologically unequal exchange and ecological debt", Special Section of the Journal of Political Ecology 23: 328-491.
} 
Forman parte de un intercambio ecológicamente desigual pero lo que es desigual no es el intercambio de recursos naturales o de energía sino la apropiación de los sumideros que absorben estas sustancias. Hace falta un nuevo concepto tal como apropiación desigual de sumideros de carbono para aclarar esta diferencia.

Palabras clave: deuda ecológica, intercambio ecológicamente desigual, apropiación de sumideros, apropriación desigual de sumideros de carbono.

\section{Introduction}

The notions of ecological debt and ecologically unequal exchange have developed in isolation from each other and under different circumstances, the former being primarily a political concept and the latter a theoretical one. Bringing them together is rare, but was pioneered by Martinez-Alier (2002) and has occurred in partnerships between activists and academics, such as the EJOLT (Environmental Justice Organizations, Liabilities and Trade) project.

I will argue that the two concepts can be linked together analytically in a fashion that is quite simple and logical, through the use of a stock versus flow perspective. Ecological debt, as it is usually conceptualized by activists and academics, is the accumulated result of different kinds of uneven flows of natural resources and waste, but these flows are seldom referred to as ecologically unequal exchange. Ecologically unequal exchange, on the other hand, is usually defined as different flows of resources and waste, but the accumulated results of these flows are seldom referred to as ecological debt.

Thus, linking these two notions in terms of a relation between a stock and a flow, where ecological debt is the accumulated result of ecologically unequal exchange, makes immediate sense. Doing so might enhance the clarity and usefulness of both concepts - and perhaps also help bridging the contexts in which they have emerged, i.e. environmental justice activism and critical academic research.

In this article, I will compare influential definitions and conceptualizations of ecological debt and ecologically unequal exchange and also attempt to link them together. A particular challenge for this enquiry is presented by emissions of substances that have global consequences, most importantly carbon dioxide and other greenhouse gases. The carbon or climate debt is usually included as part of the ecological debt, but there is no consensus on how carbon emissions should be included in a calculation of ecologically unequal exchange. I propose a new concept, unequal sink appropriation, or the more specific carbon sink appropriation, as a way of bridging this gap.

\section{Ecological debt}

Ecological debt is a concept first elaborated among environmental justice organizations in Latin America and used mainly for political purposes with the aim of mobilizing public opinion to recognize the exploitation of the South by the North, and to support financial debt relief. More recently it was it further elaborated by academics and official bodies. This background is outlined in a recent article (Warlenius et al. 2015), where the concept is summarized as "an indicator of the cumulative, or net sum, of historical environmental injustices." It is often seen as a debt between countries, but it can be applied to different scales (eg. national or local contexts), other actors (eg. corporations vs. residents, high-income vs. low-income households), or temporalities (historical debts, inter-generational debts, or mixes). Here, the focus is on how influential (North-South) conceptualizations of ecological debt can be categorized into basically three types.

After the examination of $\mathrm{EJO}^{2}$ position articles on ecological debt, sociologist James Rice (2009) summarizes their view on ecological debt as the cumulative result of a socio-ecological subsidy, i.e. a subsidy "paid" in ecological terms by Southern countries that makes possible the welfare and high-consumption lifestyles of the Northern countries. The debt began to accumulate during colonialism but has continued to accrue in post-colonial times through the economic dominance of Western corporations and through the terms

\footnotetext{
${ }^{2}$ Environmental justice organizations.
} 
of world trade, which tend to disadvantage the South. In Rice's argument, as well as in most of the EJO policy articles he analyzes, the concept is used in this general sense with the purpose of maximizing political support. The concept is not clearly defined, although it is used in a fairly consistent way. It includes both "underpayment and, at times, explicit looting of the natural resource assets and labor power." The debt accrual is manifested through trade, in "asymmetric political-economic relations; Southern environmental degradation [is] tied to exchange relations with the North", but it is also described as a general, "illicit appropriation of the environmental space of Southern countries", implying a wider, non-trade-based exploitation (Rice 2009).

In academic contexts, more precise definitions have been offered. For Martínez-Alier (2002) ecological debt is an economic concept that arises from distribution conflicts of two kinds. The first is ecologically unequal exchange, which is defined as "the fact of exporting products from poor regions and countries, at prices which do not take into account the local externalities caused by these exports or the exhaustion of natural resources, in exchange for goods and services from richer regions" (p. 214). The second type of conflict leading to ecological debt is the disproportionate utilization of the environmental space of other countries without paying for it. This tendency primarily refers to the use of carbon sinks, and is an important factor in the accrual of carbon or climate debt. Based on Martínez-Alier's understanding, ecological debt can therefore be described as the cumulative result (or stock) of trade-based ecologically unequal exchange plus the carbon debt, i.e. the continuous, disproportional appropriation of global carbon sinks.

An even more precise definition is presented by Paredis et al. (2008: 149). The two key concepts applied are "ecological damage" and "use at the expense of the equitable rights of others." An ecological debt has thus accrued when one country causes ecological damage in another country or to the global commons. Accrual can also be said to have occurred in situations where disproportionate use has been made of ecosystem services that should have been shared equally by all on Earth.

This definition is similar to Martínez-Alier's conceptualization of the two distributional conflicts that lead to the accrual of ecological debt, where his first category-the cumulative effects of ecologically unequal exchange — corresponds to ecological damage done outside a country's own territory, and his second category-disproportionate use of the global commons - to "use at the expense of the equitable rights of other countries." Together, these categories well reflect the "socio-ecological subsidy" identified by James Rice.

Consensus has thus developed around the concept of ecological debt, from the EJO policy articles analyzed by Rice through more academic elaborations. Yet, there are ambiguities and differences, and the most relevant in the current context regards the quality of the ecological debt. I propose that these are of three kinds. First, if the debt has accrued because of a "subsidy" (Rice 2009) or underpayment (Martínez-Alier 2002), the conclusion must be that it is a matter of economics, and that if the same natural resources had been exported under more favorable terms of trade, the debt would not have arisen. A second kind of ecological debt refers to its biophysical contents. In several studies (e.g. Azar and Holmberg 1995; Jenkins 1996; Paredis et al. 2008; Smith 1996; Srinivasan et al. 2008; Torras 2003), ecological debt is measured empirically in biophysical units (although also valued in monetary terms). For instance, Srinavasan et al. (2008) use six major measures - climate change, stratospheric ozone depletion, agricultural intensification and expansion, deforestation, overfishing, and mangrove conversion-to calculate the ecological debt owed by high-income to low-income countries. Either through force or economic power, some parts of the world have been drained of their resources. Instead of measuring the debt in dollars, units such as tons of minerals or hectares of rainforest cleared, can be used.

Since the turn of the millennium, there has also been a greater emphasis on carbon and climate debt as part of a larger ecological debt. The definitions of ecological debt that had previously been developed could quite easily absorb this shift of focus, referring to the disproportionate use of environmental space, or, as Paredis et al. (2008: 149) put it, use occurring "at the expense of the equitable rights ... of other countries or individuals." In the case of carbon or climate debt, it clearly makes sense to measure the debt in biophysical terms, i.e. in tons of carbon or greenhouse gases (Botzen, Gowdy and van den Bergh 2008; Paredis et al. 
2008; Warlenius 2012), not least in the context of NGO campaigning (Action Aid 2009; Christian Aid 2009; FOEI 2005; Jubilee Debt Campaign 2007; Simms 2009; Simms et al. 1999; TWN 2009) and in climate diplomacy (UNFCCC 2009, 2010).

To consider ecological debt as strictly a matter of underpayment or biophysical imbalance is, however, difficult to reconcile with cases of ecological debt that are hard to compensate for in monetary or biophysical terms. If, for instance, the livelihoods of complete societies have been destroyed, as in the case of the oil extraction in Ecuador or the Niger delta (cf. Greyl et al. 2013; Temper et al. 2013), if species have been exterminated or ecosystems ruined, it is inappropriate to argue that these are cases of underpayment and would not have arisen under more favorable terms of trade. In more recent work, Martínez-Alier has stressed the incommensurability between ecological losses and economic compensation (e.g. Rodríguez-Labajos and Martínez-Alier 2013), arguing that, rather than increasing prices, the most important repayment of the ecological debt is to stop the accrual of further debt (Martínez-Alier 2015). This points to a third kind of ecological debt that is closer to what Paredis et al. refer to as "damage", which is a moral and legal debt. This kind of debt is harder to quantify, it can even be immaterial as in the case of 'biopiracy', when genetic information is appropriated and enclosed through patents, and it is punitive rather than compensatory.

For now I will conclude that ecological debt is a multifaceted concept that seems to escape a concise, all-encompassing definition. Yet, these conceptualizations can be boiled down to three categories: Underpayment debts, biophysical debts, and punitive debts. The first is measured in money, the second in physical units and the third escapes quantitative measurement, but might still be repaired monetarily more or less symbolically.

\section{Ecologically unequal exchange}

\section{Unequal exchange}

To find a precise and generally accepted definition of ecologically unequal exchange is perhaps even more difficult than for ecological debt, mainly because there are several definitions and applications already in use. The background of this concept is quite different from ecological debt; it emanates from theories of economic unequal exchange, with a long history going back at least to the classical economists of the nineteenth century. The concept gained a renewed interest in the 1960s and 1970s, mainly among Marxists and dependency theorists. Most theories of (economic) unequal exchange gravitate toward the idea of more labor of peripheral nations being exchanged for less labor from core nations in a capitalist world-system, but they diverge from each other in some aspects.

In 1817, David Ricardo's theory of the comparative advantages of international trade acknowledged that the result of trade between countries with different levels of labor productivity would be an exchange of more labor for less (cf. Foster and Hollemann 2014), but he still regarded the exchange as mutually beneficial. Marx, however, saw this as an exploitative relation where "the privileged country receives more labour in exchange for less" and obtains "a surplus profit" (Marx 1981: 345). The Marxian theory of unequal exchange was further developed by Otto Bauer in the context of the multinational Habsburg empire. A consequence of the German parts of great Austria being more advanced than the Czech parts was a higher organic composition of capital in the former-i.e. a higher proportion of constant capital (machinery, buildings etc.) than variable capital (labor) as components of total capital. Whereas Ricardo assumed immobility of capital between countries, Bauer in his intra-empire context assumed mobility of capital between different regions of the empire and, since capital is drawn to maximum profit rates, a tendency toward profit equalization.

According to Marx, surplus value is the value produced by labor above wages, and the rate of profit the ratio between surplus value and invested capital-both constant and variable. However, since constant capital is already valorized and not able to change in the short term, a change in the rate of profit due to equalization will have to occur by means of the surplus value derived from labor. If equal profits are to be 
made from investments in sectors with different organic compositions of capital, extraction of surplus value from labor in the more labor-intensive sectors has to be higher:

It all happens as though the surplus value produced in the two areas were first of all cast into a heap and then shared out among the capitalists according to each one's holding of capital. Thus, the capitalists of the more highly developed areas not only exploit their own workers but also appropriate some of the surplus value produced in the less highly developed areas. If we consider the prices of commodities, each area receives in exchange as much as it has given. But if we look at the values involved we see that the things exchanged are not equivalent (Bauer 2000: 200; translation following Emmanuel 1972: 175).

This concept of unequal exchange resulting from different levels of organic composition of capital is typical within the Marxist tradition, but was challenged by Arghiri Emmanuel. He referred to this as "unequal exchange in the broad sense" or "non-equivalent exchange" (Emmanuel 1972: 160-163; cf. Brolin 2006: 52). What makes it broad is that it also exists within national economies, where value is transferred from sectors with organic composition below average to sectors with organic composition above average. This inequality can be seen as a compensation for the larger amounts of past labor (i.e. constant capital) embodied in the products made in a system with higher organic composition.

Unequal exchange in the strict sense, according to Emmanuel, is a result not of differences in the organic composition of capital but of wage differences or different rates of surplus value extraction-the ratio between the amount of surplus value and the amount of wages - that exist due to different institutional settings and the immobility of labor between countries.

[U]nequal exchange is the proportion between equilibrium prices that is established through the equalization of profits between regions in which the rate of surplus value is 'institutionally different' (Emmanuel 1972: 64, italics in original).

The "institutionally different" wages are often a historical coincidence, but they generate a selfperpetuating dialectical process. High wages encourage the substitution of technology for labor, thus leading to technological development, higher education, and trade-union organization-processes that generate yet higher wages. In addition, high wages and the rising organic composition of capital compel other countries to pay for it through unequal exchange. "Wealth begets wealth" (Emmanuel 1972: 131), and "Poverty begets poverty", the latter because low wages lead to an export of a large part of the country's surplus to the highwage countries and thereby deprives itself of the means of accumulation and growth. This stagnation keeps capital scarce, organic composition low, and unemployment high_conditions which all exert a downward pressure on wages. Importantly, according to Emmanuel (1972: 123-126), it is high wages that is the original cause of industrial development, not the other way around. Wages are the independent variable of his model.

Although the hypothesis makes intuitive sense, Emmanuel's attempts to show analytically exactly how value is transferred from low-wage to high-wage countries, adopting first Marxian, later Sraffian terminologies, were not always successful and never easy to follow (cf. Brolin 2006, ch. 7). It was also criticized, by Marxists (e.g. Bettelheim 1972, Mandel 1975) and neoclassical economists (for an overview, see Brolin 2006: 182). For Marxists, making wage levels the independent variable in unequal development was particularly disturbing. They tend to acknowledge the importance of wage differences but regard them as a result of, rather than the cause of, an imperialist and neo-imperialist world order. After a history of direct rent transfer from the colonies to the cores, ultimately based on military force, the importance of unequal exchange - i.e. the exchange of more embodied labor for less-became an important factor after the Second World War and the decolonization of most of the global South. Marxists explained such unequal exchange by differences in productivity and the organic composition of capital rather than by differences in wages (Mandel 1975). 
Emmanuel assumed that while labor is confined to nations, capital is internationally mobile, which means that a tendency toward profit equalization is active also at the international level. In this sense, as Nordlund (2010: 164) emphasizes, Emmanuel was adhering to the neoclassical assumption of "free international trade and perfect competition, void of market irregularities." This is contrary to structuralist and Marxist views of the global market as distorted by asymmetric power distribution and deteriorating terms of trade (e.g. Singer 1950), monopoly capitalism (Baran 1957; Baran and Sweezy 1966), the development of underdevelopment (Frank 1966), or uneven development (Mandel 1975).

While most theorists of unequal exchange agree that power relations within the capitalist worldsystem are at the core of the question, the concept is sometimes reserved specifically for trade of unfinished primary products for industrial products, while other theorists see its mechanisms as independent of such particular conditions. Emmanuel is quite clear on this issue:

The copper of Zambia or the Congo and the gold of South Africa are no more primary than coal, which was only yesterday one of the chief exports of Great Britain; sugar is about as much 'manufactured' as soap or margarine and certainly more 'manufactured' than Scotch whisky or the great wines of France; before they are exported, coffee, cocoa, and cotton (especially cotton) have to undergo a machine processing no less considerable, if not more so, than in the case of Swedish or Canadian timber; petroleum necessitates installations just as expensive as steel; bananas and spices are no more primary than meat or dairy products. And yet the prices of the former decline while those of the latter rise, and the only common characteristic in each case is that they are, respectively, the products of poor countries and the products of rich countries (Emmanuel 1972: xxx).

Thus, according to Emmanuel, the reason why some countries seem to be permanently unable to develop is not because of the nature of their production but because of their low wage structure. A drastic yet telling example is the development of Britain's five former settler colonies. Four of them-USA, Canada, Australia, and New Zealand-are among the richest countries in the world, while the fifth-South Africahas remained poor, a semi-periphery at best. The only difference between them that has explanatory value, according to Emmanuel (1972: 124-126), is the following: in the first four former colonies the natives were almost exterminated, and the remaining fractions settled in permanent reservations outside of the national economy, while most labor was conducted by European (mostly English) emigrants already used to relatively high wages and even more unwilling to toil for low wages in a country with an abundance of free land which made farming an accessible alternative to employment. In South Africa, however, the native people were employed as low-wage labor in mines and on the fields. If the Bantus were instead exterminated and replaced by white, high-wage labor, South Africa would soon "catch up", Emmanuel argued. The gold mines, for instance, would either close because of rising labor costs, or the price of gold would rise to meet the international demand. It could be added that rising labor costs would probably encourage mechanization, which would make both high wages and competitive prices feasible. Thus, in his view, there are not "certain products that are under a curse" (p.xxx), but certain institutional settings that explain unequal exchange.

In summary, unequal exchange in the classic, economic sense tends to describe an exchange of commodities embodying unequal amounts of labor, resulting in a transfer of value, from poorer countries to richer. Yet, there are disagreements over why this is happening: due to different profit rates, varying degrees of mechanization, different wage levels, or unequal power relations more generally.

\section{Ecologically unequal exchange}

The development of an ecological theory of unequal exchange - initially defined as the exchange of more 'natural values' for less - started with Stephen Bunker $(1984,1985)$ and has been further developed by Alf Hornborg (1992, 1998, 2001, 2009, 2011), Joan Martínez-Alier (2002), Andrew Jorgenson (2006, 2009, 2016), James Rice (2007a, 2007b, 2009b) and John Bellamy Foster and Hannah Holleman (2014), among 
others. These writers are mostly aligned with the tradition of world-system analysis, while their methodologies have been influenced by studies conducted by scholars from natural sciences, particularly the ecological footprint concept developed by Rees and Wackernagel (1992), material flow analysis (cf. FischerKowalski 1998), and Howard T. Odum's 'emergy' concept (1996). In a few cases it has also been connected to the concept of ecological debt (Martínez-Alier 2002).

As predicted by Bunker in 1984 - "The flow of energy and matter to the core economies provides us a measure of the progressive subordination of the periphery and the progressive impoverishment of social organization there" - this marriage of "structuralist" concepts and "ecological economical" methodologies has produced an impressive amount of empirical articles confirming the basic assumptions about a worldsystem where the social metabolism of core countries far exceeds their domestically extracted energy and matter, and where global sinks are appropriated for the absorption of their effluents (e.g. Austin 2012; Clark 2009; Giljum and Eisenmenger 2004; Jorgenson 2006, 2010; Jorgenson et al. 2009; Jorgenson and Lawrence 2009; Pérez-Rincón 2006; Shandra et al. 2009; Vallejo 2010; Yang et al. 2014).

One criticism directed at the concept of ecologically unequal exchange (EUE) is that it lacks a coherent theory able not only to show the unequal flows of biophysical resources, but also to explain them and relate them to the world-system. Brolin (2006: 336) contends that ecologically unequal exchange poses an "obvious lack of theoretical sophistication" and advocates a reconnection to Arghiri Emmanuel, while Foster and Holleman (2014) claim that the concept is "under-theorized" and set out to fill the gap with Odum's emergy approach, which is somewhat surprising since the emergy framework is a very elaborated methodology but, arguably, of limited theoretical and explanatory value.

I agree, but only in part. The conceptualizations are sometimes vague, and there is some confusion over whether this is a method or a theory, encompassing traded goods only (as in economic unequal exchange) or the total socio-ecological interaction or metabolism of the world-system. Sometimes, researchers have been too eager to test the concept on empirical data without reflecting fully over what is actually being measured.

But there are also at least four serious attempts at basing EUE on social theories. 1) Foster and Holleman (2014) merge it not only with Odum, but also with the Marxian theory of metabolic rift developed by Foster (1999, 2000). Jorgenson's (2006) structuralist theory of unequal ecological exchange is rooted in dependency theory and world-system analysis. Bunker (2005) and Rice (2009) use Schnaiberg's (1980) theory of the treadmill of production. 2) The most original theory of EUE is, arguably, that of Hornborg (1998, 2001, 2009, 2011, 2014), combining elements from world-system analysis, thermodynamics, ecological economics, semiotics, and a profound reinterpretation of technology. He explains the parallel underdevelopment of peripheries and development of cores using thermodynamic concepts. Biophysical resources with high exergy (roughly, the ability to perform work) are extracted and imported to the cores, where they are dissipated and (partly) returned to the peripheries in the form of industrial products as well as entropic waste. While these thermodynamic flows are measured in biophysical metrics (e.g. ecological footprints, exergy, labor time, or yields per hectare), they have to be analytically separated from valuation and prices, which are determined by cultural preferences and power relations. Machines and advanced technology, Hornborg asserts, reproduce this global system of unequal exchange by transferring energy and matter from one part of the world-system to the other. This displacement of work and environmental loads is ideologically disguised as productive, but only serves to deepen the global inequalities even further. One way of measuring uneven flows of exergy is by reducing it to labor hours and yields per hectare, and compare how these are valued monetarily depending on where in the world-system they are applied for commodity production (Hornborg 2006). The method is called "time-space appropriation" and, when applied to the trade of North American cotton and English textiles in the mid-nineteenth century, revealed a massive net transfer of labor hours and hectare yields to England from its colonies. 3) In applying the same methodology to the trade between Sweden and China in the eighteenth century, Warlenius (2016) found that China, the net receiver of embodied land and labor in the case study, may have been more central in the early modern world economy than Europe. 4) In a recent article, Dorninger and Hornborg (2015) use EEMRIO (environmentally- 
extended multi-regional input-output) analyses to show that high-income countries are net-importers of raw material, energy, land and labor, which strengthens the ecologically unequal exchange hypothesis.

Hornborg (1998) has criticized conceptualizations of unequal exchange that are based on theories of embodied resources as value, e.g. those that assert that biophysical factors such as embodied energy or labor are equivalent to value, since valuation is cultural and has to be separated from physics. He has further argued, against notions of unequal exchange based on claims that primary resources in world trade are being "undervalued", that this is a meaningless proposition since energy and matter have no natural value outside how they are culturally valued and therefore cannot be undervalued in any objective sense (Hornborg 2014a, b). But even if no 'undervaluation' exists in any essential meaning or in relation to a supposed 'correct' price, the point of measuring trade in terms of biophysical flows is to expose that the hegemonic, neo-classical focus on prices conceal that labor and biophysical resources are valued differently in different parts of the world-system. Defined as "an asymmetric net flow of biophysical resources ... that is obscured by the apparent reciprocity of market prices" (Dorninger and Hornborg 2015, italics in original), ecologically unequal exchange is mainly driven by the fact that biophysical resources from the peripheries are cheaper than those from the cores; and the conclusion that there is an 'underpricing' of peripheral resources in a relative sense, when compared to the higher prices for metropolitan resources, is not very far-fetched. ${ }^{3}$ "Ultimately, what keeps our machines running are global terms of trade", Hornborg writes (2011: 9).

Yet, as far as I can see, how these 'global terms of trade' actually work to support an ecologically unequal exchange remains under-analyzed. I suspect, however, that the reasons why prices for energy-matter are lower in the peripheries are largely the same as the reasons for why wages are lower. For instance, Immanuel Wallerstein (2004: 28) refers to unequal exchange as a flow of surplus value from companies submitted to free market competition (peripheral production processes) to (quasi)monopolized, price-setting companies mainly in the cores. An intense competition puts a downward pressure on both wages and factor prices, and if the trading partners are less exposed to competition, it could explain an unequal exchange of any sort. ${ }^{4}$ Further, irrespective of whether low wages is the dependent (Bauer, Mandel) or independent (Emmanuel) variable, it will favor labor-intensive rather than capital-intensive export production. Alongside services, this normally implies agriculture and mining, sectors that are a) highly exposed to competition and often not very profitable (which establishes a link between low wages and low prices), and b) highly resource intensive (which links low wages and resource extraction). ${ }^{5}$

While economical unequal exchange is most often a matter of trading 'more labor for less' and ecologically unequal exchange a matter of exchanging 'more resources for less', a preliminary conclusion is that unequal exchange corresponds to the second, biophysical conceptualization of ecological debt. Further, as demonstrated, the driver of unequal net flows of labor and biophysical resources are world market price differences; if labor and natural resources were not priced differently in different parts of the world-system (and the social costs of bulk transport not externalized, almost entirely), world trade would certainly be a fraction of what it really is. One important achievement of the ecologically unequal exchange literature is that it has managed to expose that prices reflect power structures, and that the market value of biophysical volumes of resources vary. Thus, monetary valuation and biophysical flows are clearly connected in the sense that terms of trade influence the size of biophysical flows. That does not mean that it is possible to 'objectively' settle a 'correct' price-as Hornborg insists, it's better to keep biophysics and valuation processes

3. Most empirical studies generally confirm a pattern of "underpricing" of peripheral products in this sense, but it is of course important that conceptualizations of ecologically unequal exchanges are constructed in a way that do not presuppose a biophysical flow from South to North, but leave the cases open to individual examination (cf. Brolin 2006: 321).

4. The follow up question would be why levels of competition vary, and the short answer would be economic and political power. For instance, the Structural Adjustment Programs enforced upon developing states with large external debts by the World Bank and IMF usually include measures to increase competition in and between peripheral economies.

5. Although Emmanuel is correct in his observation that peripheral countries do not exclusively produce "primary" goods, his argument is nonetheless that a low-wage structure discourages high levels of capitalization, and therefore leads to continued exports of products that are mainly labor- (and resource-) intensive. 
separated - but the direction should be clear: improvements in the terms of trade for peripheral countries would most likely temper the unequal exchange of both labor, matter, and energy.

One analytical problem remains to be solved, however. Thi is the link between ecologically unequal exchange and the part of the ecological debt conceptualized either as the utilization of the environmental space of other countries (Martínez-Alier) or as use at the expense of the equitable rights of other countries (Paredis et al.).

\section{Unequal sink appropriation}

The concept of ecologically unequal exchange has its roots in trade theory, and from Stephen Bunker onwards it is often described as a theory of how international trade operates as a mechanism for exchanging more matter-energy for less. This does not do full justice to the approach to EUE as a theory of global socioecological metabolism that also reckons with environmental load displacements that are not normally traded, such as absorption of waste and pollution in general and of carbon dioxide in particular. Sometimes, as in the case of Martínez-Alier (2002: 214), the utilization of the environmental space of other countries, i.e. for waste absorption, is regarded as external to ecologically unequal exchange. However, this does not exclude inclusion of fossil fuels as such. On the contrary, oil, coal, and gas are schoolbook examples of ecologically unequal exchange. They produce vast ecological and social destruction and distribution conflicts at the point of extraction, which is often situated in peripheral countries, and they are imported to and most intensively used in the cores, where they constitute a crucial input in the socio-ecological metabolism. The trade in fossil fuels thus appears to maintain and widen the gap between under- and (over)developed countries.

But fossil fuels treated as a primary commodity have a different dynamic than when they are treated as the most important cause of climate change. This second dynamic has some peculiarities. To begin with, climate change is a global threat of gigantic proportions, whereas most environmental issues are first and foremost local problems. Furthermore, the spatial correlation between pollution and environmental effects is completely absent for climate change: local climate related effects will occur as a result of increased atmospheric concentration of carbon dioxide independent of where the emissions have occurred. Although ecological destruction at the sites of oil extraction is often devastating, it is still very far from the severity of climate change. Another peculiarity is the extremely high economic value of fossil fuels for global capitalism, as no feasible substitution is arguably available. If ecologically unequal exchange is simply regarded as a trade theory, it can include the first dynamic of fossil fuels (asymmetric transfers of energy), but not the second dynamic (climate change). This approach would be consistent with its roots in trade theory, but it would come at the price of making EUE less relevant as a concept for understanding the full global distribution of environmental problems. Let us therefore have a look at the few attempts at integrating carbon emissions into EUE.

One way to include carbon emissions is to measure unequal exchange in terms of ecological footprints, which calculates six ecological burdens of which carbon absorption by forests is one, or in terms of environmental space, which comprises both resource extraction and waste assimilation. Rice (2007b) therefore tests a hypothesis derived from the theory of ecologically unequal exchange, defining it in a way that also includes the appropriation of external sink capacities (2007b: 1383), yet without thoroughly reflecting on its consequences for EUE as a trade theory. Jorgenson $(2011,2012)$ makes a more conscious attempt at integrating carbon emissions in ecologically unequal exchange, but without transcending the framing of EUE as a trade theory. He finds, to his own surprise, that "research in the ecologically unequal exchange tradition has neglected to assess if the vertical flow of exports contributes to increases in carbon dioxide emissions, especially in lower-income countries," which he regards as a limitation that is "far beyond trivial" because of the severity of climate change (2012: 244). He thus shows empirically that, for both peripheral and semi-peripheral countries, exports tend to co-vary with emissions of carbon dioxide. This "illustrates the growing environmental impacts of structural relationships between societies, and how the consequences are disproportionally felt by nations in the Global South" (Jorgenson 2012: 250), while also the 
exports of Central and Eastern Europe lead to "environmentally harmful" carbon emissions (Jorgenson 2011: 112).

Jorgenson's efforts to transcend this limitation of previous EUE research is praiseworthy, and the results are important, showing that carbon-intensive activities are increasingly dislocated to Eastern Europe and the global South. However, his conclusion that such displacements of carbon emissions increase the environmental impacts in the receiving countries is flawed, since it fails to integrate the peculiarity of the spatial disconnection between emissions and climate change mentioned above. Climate change will not affect the peripheries more because of the trade-related effects of ecologically unequal exchange that Jorgenson examines (unless globalization causes an overall increase in global emissions, which is possible but not demonstrated by his studies). His analysis, however valuable, therefore fails to grasp important aspects of the relation between carbon emissions and unequal exchange.

In an article by Moran et al. (2013), carbon emissions are integrated into ecologically unequal exchange as embodied emissions in trade. The authors set out to test the existence of EUE - defined as "natural resources being extracted from resource-rich but cash-poor countries to satisfy consumer demand in wealthy countries" - using a global multi-region input-output table for the trade between 187 countries in terms of eight indicators of environmental pressure of which one is emissions of greenhouse gases. Carbon emissions are measured as embodied in exports and compared with financial flows. The expectation, if EUE occurs, is that exports from low-income countries are more carbon-intensive than those from high-income countries, and that a large part of the embodied emissions of high-income country consumption are emitted in the territories of low-income countries. While the first hypothesis is largely confirmed, the second is not. According to the authors, "the explanation must be that the large volume of relatively clean exports flowing out of higher income nations overrides the smaller volume of more ecologically intensive exports from lower income nations", and they thus conclude that "the hypothesis that high-income nations disproportionately exert ecological impacts in lower income nations is false" (Moran et al. 2013).

This conclusion can be questioned empirically, and has been done so convincingly by Dorninger and Hornborg (2015). The aim here, however, is to question it analytically. Although the effort to measure net flows of embodied carbon is a methodological improvement, the article reproduces the disturbing tendency to consider carbon dioxide a local pollutant rather than a global problem.

$\mathrm{CO}_{2}$ does not have to be emitted in low-income countries for high-income countries to exert ecological impacts on them-in fact, it is irrelevant where the emissions occur. What matters is that highincome nations are disproportionally responsible for excess emissions of $\mathrm{CO}_{2}$ caused by its disproportionate levels of consumption, which will exert enormous ecological impacts (mainly) on low-income countries through climate change. The way in which Moran et al. integrate carbon into EUE is therefore, I would argue, a misconception, probably based on the conceptualization of EUE as exclusively a trade theory.

For Hornborg (2011: 55, 80-81), carbon emissions are instead integrated into ecologically unequal exchange through the thermodynamic concept of entropy. Carbon dioxide from fossil fuel combustion is regarded as entropic waste which is absorbed in global sinks, but the use of these sinks is unevenly distributed between central and peripheral countries due to their vastly different per capita responsibility for carbon emissions. This perspective emerges if we treat EUE as a concept of wider application than merely trade-related environmental displacements, in order to grasp the full socio-ecological interaction between cores and peripheries in the world-system. Whether to do so or not is of course open to discussion, as it distances the concept from its original meaning, but I would argue that the pros outweigh the cons.

An attempt at elaborating on climate change as the result of unevenly produced entropic waste and integrating it into the theory of ecologically unequal exchange would be to propose the concept of unequal sink appropriation (or, in the case of climate change, the more particular concept carbon sink appropriation). It is meant to apply to those peculiar effluents of capitalist social metabolism—such as greenhouse gases and substances that harm the ozone layer-whose impacts are not related to the distance to the tailpipe, but which are retained in sinks on land or in the sea or spread out in the atmosphere, affecting the Earth system as a whole. These sinks have historically not been allocated either through regulation or the market but simply 
appropriated by the emitters. Only when they have been filled and started to leak, have they come to the attention of global regulators. Through the Montreal Protocol in 1987, the emissions of substances that harm the ozone layer were halted, but despite hard efforts within UNFCCC for over 20 years, no effective regulation of greenhouse gases exists, and the unequal appropriation of the global carbon sinks is still ongoing, leading to alarming levels of GHGs in the atmosphere.

\section{Linking Ecological Debt and Ecologically Unequal Exchange as stocks and flows}

To merge all the various definitions of ecologically unequal exchange and ecological debt is hardly possible. As shown, both concepts are in themselves prone to divergent definitions, variably tailored for political mobilization, legal cases, or social analysis, focusing on ecological injustices measured in money, biophysical resources or damage. Yet, as long as the definitions are consistent with each other, the concepts of ecological debt and ecologically unequal exchange can be linked together analytically through a stockflow perspective irrespective of which of these approaches that is chosen.

Within ecological economics, the terms "stock" and "fund" are used to distinguish between two different kinds of resources. Daly and Farley (2011: 70-72) illustrate this difference with the example of a pizza. To make a pizza you need inputs of different kinds: ingredients (flour, tomatoes, cheese, etc.) will be consumed while transforming them into the pizza, but you also need a cook, utensils, and an oven that together transform the ingredients into a pizza without being consumed themselves (just slightly worn). The ingredients, or raw materials, are stock (or stock-flow resources), while the utensils, etc. are fund (or fundservice) resources. The basic difference between the two is that a stock-flow resource is transformed in the production process, while the fund-service resource conducts the transformation.

To transform something requires a temporal aspect, which is lacking in what is being transformed. If we have enough ingredients for 1,000 pizzas, they can either be made all at once or spread out over time time does not define the existence of this stock of potential pizzas. The limiting factor is the fund resource: the capacity of the oven, for instance. The speed (or flow) of pizza-making determines the rate of consumption of the stock. While the stock is measured as $\mathrm{X}$ units at a specific point in time, a flow is measured over an interval of time, as $\mathrm{X}$ units per $\mathrm{Y}$ units of time. Stocks and flows are not immediately commensurable, but are easy to relate by adding time. Quite simply, if I have 10 dollars in my piggy bank, and I add 1 dollar every month, the stock is measured in dollars and the flow in dollars per month. Another, more pertinent example is the relation between a debt (stock) and the money flows that determines the debt: lending, interest, redemption, etc. Here, the stock (debt) is the accumulated result of the flows measured at a specific point in time.

The fund resource also has an inherent temporal aspect. For instance, the oven has a fixed capacity to produce a number of pizzas per time unit (a service); it cannot make all the pizzas at one time. A fund is worn out, while a stock is used up. It is important to remember, however, that the distinction of stocks and funds is functional and contextual: the oven is a fund in pizza-making, but a stock when piled up in a department store.

Natural resources are stock-flow resources. They are transformed rather than transform. This goes for biotic resources-food, biofuels, etc.-as well as abiotic resources such as minerals and fossil fuels. The argument can also be extended to include waste, including effluents and emissions. They are byproducts of all stages of the economy: extraction, distribution, and consumption. In the end, most products end up as garbage. The global social metabolism generates a constant flow of waste. Although parts of it is recycled by humans or biodegraded by ecosystems, a large amount of it will pile up as waste stocks, either in garbage dumps, increasingly after having been exported to Africa or Asia, in the rivers, lakes and seas, in the soil, or in the atmosphere.

Recalling Arghiri Emmanuel's comment quoted above, however, unequal exchange is not restricted to primary resources but can also take place under an exchange of manufactured products. Therefore, fund resources such as ovens or machines can also be part of an unequal exchange; but in the context of a trade exchange, also machines are stocks. They do not become fund resources until they are installed in the factory 
and production begins. From the point of view of unequal exchange, thus, all products are stock-flow resources.

When these flows of resources and waste are international, they tend to be asymmetric. More resources flow from the peripheries of the world-system than the other way around. In thermodynamic terms, Southern countries are drained of exergy, which is used to fuel consumption and capital accumulation in Northern economies. Net flows of waste tend to go in the other direction. Huge amounts of electronic waste, tires, cars, and even old ships are dumped in Africa or Asia. Excess emissions of carbon dioxide and other greenhouse gases spread out evenly in the atmosphere, but the responsibility is unequally distributed: about three-quarters of historical carbon emissions contributing to climate change have been emitted in the global North, which contains only one-fifth of the global population. The effects of climate change are also unequally distributed, but in inverse relation to responsibility. About three-quarters of the costs for climate change are predicted to burden the global South:

The net flows of natural resources, other products, wastes, and sink appropriations, we call ecologically unequal exchange. The cumulative stock resulting from these historical net flows, we call ecological debt (UNDP 2007). ${ }^{6}$

\section{Final considerations on the use of linking Ecological Debt and Ecologically Unequal Exchange}

The point of this exercise, as stated already in the introduction, is twofold. First, to link ecological debt and ecologically unequal exchange together using a stock-flow perspective. I have claimed that there are three main ways of conceptualizing ecological debt: as a monetary debt, a biophysical debt, and a punitive debt. Ecologically unequal exchange, on the other hand, is always conceptualized as biophysical flows of matter and/or energy. The most natural match would therefore be to link biophysical debt to biophysical flows, and in most cases, I regard this as the most interesting approach. But in principle, a monetary debt could also be related to a flow. Even a punitive debt can be related to a flow of historical abuses, but would be hard to quantify and calculate. Thus, as long as definitions are used consistently, all kinds of ecological debts can be linked to an unequal exchange and vice versa. Some examples:

- If the weight of the net trade between Europe and Africa in 2010 is referred to as an instance of ecologically unequal exchange, the sum of the same net weight transfer from 1950-2010 could be called an instance of ecological debt.

6 It is worth noticing that stock and fund resources have their equivalents in classical political economy, where they are called fixed capital and circulating (or fluid) capital (cf. Marx 1978, ch. 8-11) or - in a general sense, "regardless of social conditions" - instruments of labour and objects of labour (Marx 1976: 283). It is perhaps confusing that stock-flow resources, which refer to a linear flow, are similar to circulating capital, even more so since Marx was well aware that the raw materials were "consumed entirely in the course of forming the particular product" (Marx 1978: 246). What is circulating is, however, the value of circulating capital: "This value is thus completely circulated via the product, transformed into money and from money back into the elements of production of the commodity" (Marx 1978: 244). Actually, also fixed capital circulates but at a slower turnover pace. Its value is transferred to the products not directly, but bit by bit; "[t]he portion of value that it loses in its natural form by wear and tear circulates as a value portion of the product" (Ibid.: 242). This goes on "until the means of labor eventually expires and its entire value has separated off from its dead body and been transformed into money" (Marx 1978: 243). Further, just as in ecological economics, Marx also regarded the difference between the two notions as strictly functional: "An ox, as a draught animal, is fixed capital. If it is eaten, however, it no longer functions either as a means of labour, or as fixed capital" (Marx 1978: 239) but as circulating capital. A machine "only becomes fixed capital in the hands of ... the capitalist who employs it productively" (Marx 1978: 240). Finally, the difference between fixed capital and constant capital should be noted: while the first relate to value turnover, the latter refer to surplus value creation. Because both fixed capital and circulating capital transfer their entire value, neither more nor less, to the product (although at different turnover times), they are called constant capital. According to Marx only labor power (which is part of circulating capital) adds more value to the products through the labor-process, and is therefore called variable capital. In the light of these great similarities, the reason why I chose the modern terminology is because of the stock-flow analogy which is suited to describe the relation between ecological debt and ecologically unequal exchange, and has no parallel in the classic political economy terminology. 
- If the Annex 1 nations' appropriation of global carbon sinks above its per capita share might be called its carbon debt, then the annual appropriation would be regarded as a kind of ecologically unequal exchange that has not been assigned an acknowledged term, but which I propose to call carbon sink appropriation.

- If the internalization of the social costs of the annual production of a coffee plantation exceeds the received factor price with $\mathrm{X}$, and $\mathrm{Y}$ is the total number of years of operation, then $\mathrm{X}$ can be referred to as a case of ecologically unequal exchange and $\mathrm{XY}$ the corresponding ecological debt.

- If the ecological devastation, social vulnerability and political oppression resulting from Shell's oil extraction in the Niger delta for over 50 years is referred to as an ecological debt to the people of the area, then the non-compensated operations, in a given historical moment such as the present, represents a kind of ecologically unequal exchange.

Linking ecological debt and ecologically unequal exchange might enhance the clarity and usefulness of both concepts and sharpen our understanding of both these phenomena. Firstly, one weak point in most approaches to ecologically unequal exchange-the exclusion of climate change-has been identified and addressed. I hope that this concept is not only of academic value, but could also help to mitigate real problems. For instance, a problem in the climate debate that is strategically used for political purposes is the conflation of momentary emissions and cumulative emissions of greenhouse gases. As we know, climate change is a consequence of cumulative emissions; yet, we hear again and again that the biggest problem is China's large, momentary emissions, even though its cumulative emissions per capita is still a fraction of those of the US or Europe. This is not to say that China's emissions are trivial, which they certainly are not, but China's historical per capita responsibility for climate change is nonetheless much smaller than that of most developed countries. A clear, conceptual link between the flows and stocks of emissions and sink capacities-between carbon sink appropriation and carbon debt-could perhaps help to resist this common misconception regarding China's responsibility for climate change.

Secondly, establishing a link between ecological debt and ecologically unequal exchange is also a way to bridge the gap between the social environments in which the respective concepts have been developed, mainly between the environmental justice activists and radical academics, who have developed practices related to respective concepts, but also among global justice activists of different backgrounds. Reading the manifestos adopted by the global climate justice movement for another research project, it struck me that while climate debt repayment is a central demand for most Southern-based movements, its Northern allies, especially those with a background in left-wing activism, are alienated from the concept and even criticize it (cf. Mueller 2012; Russel 2012: 180-184). While the Southern-dominated Climate Justice Now! network highlights climate debt repayment as one of their central demands (CJN 2007), their partner in the 2009 COP15 mobilizations, the mostly European, leftist network Climate Justice Alliance, does not mention climate debt in their post-Copenhagen analysis (CJA 2010). Since they did write about many of the premises and theories underpinning climate debt, such as Europe's historical responsibility for climate change, geopolitical inequalities and unequal exchange, the non-use of it raises the question of whether it depends on different cultural contexts rather than theoretical disagreements. It would of course be very idealistic to assume that the linking of discourses that has been attempted here would also result in a linking of the actors that carry them. But I think such a bridge, even if symbolic, between activists and between activists and scholars is a worthwhile conceptual and theoretical contribution.

\section{Bibliography}

Action Aid. 2009. Rich countries 'climate debt' and how they can repay it: an Action Aid rough guide. Johannesburg: Action Aid International.

Austin, K. 2012. Coffee exports as ecological, social, and physical unequal exchange: a cross-national investigation of the java trade. International Journal of Comparative Sociology 53: 155-180. 
Azar, C. and J. Holmberg, 1995. Defining the generational environmental debt. Ecological Economics 14: 719.

Baran, P.A. 1957. The political economy of growth. New York: Monthly Review Press.

Baran, P.A. and P.M. Sweezy. 1966. Monopoly capital: an essay on the American economic and social order. New York: Monthly Review Press.

Bauer, O. 2000 (1924). The question of nationalities and social democracy. Minneapolis: University of Minnesota Press.

Bettelheim, C. 1972. Theoretical comments by Charles Bettelheim. In Emmanuel, A. Unequal exchange: a study of the imperialism of trade. New York: Monthly Review Press. Pp 271-322.

Botzen, W.J.W., J.M. Gowdy and J.C.J.M. van den Bergh. 2008. Cumulative $\mathrm{CO}_{2}$ emissions: shifting international responsibilities for climate debt. Climate Policy 8: 569-576.

Brolin, J. 2006. The bias of the world: theories of unequal exchange in history. PhD dissertation. Lund: Lunds Universitet.

Bunker, S.G.. 1984. Modes of extraction, unequal exchange, and the progressive underdevelopment of an extreme periphery: the Brazilian Amazon 1600-1980. American Journal of Sociology 89 (5): 10171064.

Bunker, S.G. 1988 (1985). Underdeveloping the Amazon: extraction, unequal exchange, and the failure of the modern state. Chicago: University of Chicago Press.

Bunker, S.G. 2005. How ecologically uneven developments put the spin on the treadmill of production. Organization and Environment 18: 38-54.

Christian Aid, 2009. Climate debt and the call for justice: signposts to Copenhagen 5. London: Christian Aid. http://www.christianaid.org.uk/images/signposts-climate-debt.pdf

Climate Justice Alliance [CJA]. 2010. What does climate justice mean in Europe? https://ayya2cochabamba.wordpress.com/texts-and-articles/what-does-climate-justice-mean-ineurope/

Climate Justice Now! 2007. Founding statement. http://ccs.ukzn.ac.za/default.asp?4,80,5,2381

Daly, H.E. and J.C. Farley. 2011. Ecological economics: principles and applications. 2nd ed. Washington: Island Press.

Dorninger, C. and A. Hornborg, 2015. Can EEMRIO analyses establish the occurrence of ecologically unequal exchange? Ecological Economics 119: 414-418

Emmanuel, A. 1972. Unequal exchange: a study of the imperialism of trade. New York: Monthly Review Press.

Fischer-Kowalski, M. 1998. The intellectual history of materials flow analysis, part 1 \& 2, Journal of Industrial Ecology 2: 61-78, 107-136.

Foster, J.B. 1999. Marx's theory of metabolic rift: classical foundations for environmental sociology. American Journal of Sociology 105(2): 366-405.

Foster, J.B. 2000. Marx's ecology: materialism and nature. New York: Monthly Review Press.

Foster, J.B. and H. Hollemann, 2014. The theory of unequal ecological exchange: a Marx-Odum dialectic. The Journal of Peasant Studies 41(2): 199-233.

Frank, A.G. 1966. The development of underdevelopment. New York: Monthly Review Press.

Friends of the Earth International [FOEI]. 2005. Climate debt: making historical responsibility part of the solution. $\quad$ http://www.foei.org/en/resources/publications/climate-justice-and-energy/20002007/climatedebt.pdf/at_download/file

Giambellucu, T.W. and A. Henderson-Sellers (eds.). 1996. Climate change: developing southern hemisphere perspectives. Chichester/New York: Wiley. 
Giljum, S. and N. Eisenmenger, 2004. North-South trade and the distribution of environmental goods and burdens: a biophysical perspective. The Journal of Environment Development 13: 73-100.

Greyl, L., G. U. Ojo, C. Williams, C. Certoma, L. Greco, N. Ogbara and A. Ohwojeheri. 2013. Digging deep corporate liability. environmental Justice strategies in the world of oil. EJOLT Report No. 9.

Hornborg, A. 1992. Machine fetishism, value, and the image of unlimited good: towards a thermodynamics of imperialism. Man 27: 1-18.

Hornborg, A. 1998. Towards an ecological theory of unequal exchange: articulating world system theory and ecological economics. Ecological Economics 25(1): 127-136.

Hornborg, A. 2001. The power of the machine: global inequalities of economy, technology, and environment. Walnut Creek: AltaMira Press.

Hornborg, A. 2006. Footprints in the cotton fields: The Industrial Revolution as time-space appropriation and environmental load displacement. Ecological Economics 59: 74-81.

Hornborg, A. 2009. Zero-sum world: challenges in conceptualizing environmental load displacement and ecologically unequal exchange in the world-system. International Journal of Comparative Sociology 50: 237-262.

Hornborg, A. 2011. Global ecology and unequal exchange: fetishism in a zero-sum world. London: Routledge

Hornborg, A. 2014. Ecological economics, Marxism, and technological progress: some explorations of the conceptual foundations of theories of ecologically unequal exchange. Ecological Economics 105: 1118.

Hornborg, A. 2014b. Why economics needs to be distinguished from physics, and why economists need to talk to physicists: a response to Foster and Holleman. The Journal of Peasant Studies 47: 187-192.

Jarrick, A., J. Myrdal and M. Wallenberg Bondesson (eds.). 2016. Methods in global history. a critical approach. Lund: Nordic Academic Press.

Jenkins, T.N. 1996. Democratising the global economy by ecologicalising economics: the example of global warming. Ecological Economics 16: 227-238.

Jorgenson, A. 2006. Unequal ecological exchange and environmental degradation: a theoretical proposition and cross-national study of deforestation, 1990-2000. Rural Sociology 71: 685-712. Researchgate

Jorgenson, A. 2009. The sociology of unequal exchange in ecological context: a panel study of lower-income countries, 1975-2000. Sociological Forum 24:22-46.

Jorgenson, A. 2010. World-economic integration, supply depots, and environmental degradation: a study of ecologically unequal exchange, foreign investment dependence, and deforestation in less-developed countries. Critical Sociology 36: 453-477. Academia

Jorgenson, A.K. 2011. Carbon Dioxide Emissions in Central and Eastern European Nations, 1992-2005: A Test of Ecologically Unequal Exchange Theory. Research in Human Ecology 18 (2): 105-114

Jorgenson, A. 2012. The sociology of ecologically unequal exchange and carbon dioxide emissions, 19602005. Social Science Research 41: 242-252.

Jorgenson A.K. 2016. The sociology of ecologically unequal exchange, foreign investment dependence and environmental load displacement: summary of the literature and implications for sustainability. Journal of Political Ecology 23: 334-349.

Jorgenson, A., K. Austin and C. Dick. 2009. Ecologically unequal exchange and the resource consumption / environmental degradation paradox: a panel study of less-developed countries, 1970-2000. International Journal of Comparative Sociology 50: 263-284. Researchgate

Jorgenson, A. and B. Clark. 2009. The economy, military, and ecologically unequal relationships in comparative perspective: a panel study of the ecological footprints of nations, 1975-2000. Social Problems 56:621-646. Academia

Jubilee Debt Campaign. 2007. Debt and climate change. Briefing 07. London: Jubilee Debt Campaign. 
Lawrence, K.S. 2009. The thermodynamics of unequal exchange: energy use, $\mathrm{CO}_{2}$ emissions, and GDP in the world-system, 1975-2005. International Journal of Comparative Sociology 50: 335-359.

Mandel, E. 1975. Late capitalism. London: Verso.

Martinez-Alier, J. 2002. The environmentalism of the poor: a study of ecological conflicts and valuation. Cheltenham: Edward Elgar. Ch.1

Martínez-Alier, J. 2015. Calculations of the ecological debt - what are they for? In Warlenius, R., G. Pierce, V. Ramasar, E. Quistorp, J. Martínez-Alier, L. Rijnhout and I. Yanez (eds.). 2015. Ecological debt: history, meaning and relevance for environmental justice. EJOLT Report No. 18.

Marx, K. 1976[1867]. Capital: a critique of political economy. Vol. 1. Harmondsworth: Penguin

Marx, K. 1978[1885]. Capital: a critique of political economy. Vol 2. Harmondsworth: Penguin

Marx, K. 1981[1894]. Capital: a critique of political economy. Vol. 3. Harmondsworth: Penguin

Moran, D.D., M. Lenzen, K. Kanemoto and A. Geschke. 2013. Does ecologically unequal exchange occur? Ecological Economics 89: 177-186.

Mueller, T. 2012. The People's Climate Summit in Cochabamba: a tragedy in three acts. Ephemera 12 (1/2): 70-80.

Nordlund, C. 2010. Social ecography: international trade, network analysis, and an Emmanuelian conceptualization of ecological unequal exchange. PhD dissertation. Lund: Lunds Universitet.

Odum, H.T. 1996. Environmental accounting: EMERGY and decision making. New York: Wiley.

Paredis, E., G. Goeminne, W. Vanhove, F. Maes and J. Lambrecht. 2008. The concept of ecological debt: its meaning and applicability in international policy. Ghent: Academia Press.

Pérez-Rincón, M.A. 2006. Colombian international trade from a physical perspective: towards an ecological 'Prebisch thesis.' Ecological Economics 59: 519-529.

Rees, W. and M. Wackernagel. 1992. Ecological footprints and appropriated carrying capacity: measuring the natural capital requirements of the human economy. Stockholm: Second Meeting of the International Society for Ecological Economics.

Rice, J. 2007a. Ecological Unequal Exchange: consumption, equity, and unsustainable structural relationships within the global economy. International Journal of Comparative Sociology 48: 43-72. Academia

Rice, J. 2007b. Ecological Unequal Exchange: international trade and uneven utilization of environmental space in the world system. Social Forces 85 (3): 1369-1392. Academia

Rice, J. 2009a. North South relations and the ecological debt: asserting a counter-hegemonic discourse. Critical Sociology 35: 225-252.

Rice, J. 2009b. The transnational organization of production and uneven environmental degradation and change in the world economy. International Journal of Comparative Sociology 50: 215-236.

Rodríguez-Labajos B. and J. Martínez-Alier. 2013. The economics of ecosystems and biodiversity: recent instances for debate. Conservation and Society 11: 326-342.

Russel, B.T. 2012. Interrogating the post-political: the case of radical climate and climate justice movements. PhD dissertation. Department of Geography, University of Leeds.

Shandra, J.M., C. Leckband and B. London. 2009. Ecologically Unequal Exchange and deforestation: a cross-national analysis of forestry export flows. Organization and Environment 22: 293-310.

Schnaiberg, A. 1980. The environment: from surplus to scarcity. New York: Oxford University Press.

Simms, A. 2009. Ecological debt, global warming and the wealth of nations. Second Edition. London: Pluto Press.

Simms, A., A. Meyer and N. Robins, 1999. Who owes who? Climate change, debt, equity and survival. London: Christian Aid.

Singer, H.W. 1950. The distribution of gains between investing and borrowing countries. The American Economic Review 40(2): 473-485. 
Smith, K.R. 1996. The natural debt: North and South. In Giambellucu, T.W. and A. Henderson-Sellers (eds.). Climate change: developing southern hemisphere perspectives. Chichester/New York: Wiley. Pp. 423448.

Srinivasan, U.T, S.P. Carey, E. Hallstein, P.A.T. Higgins, A.C. Kerr, L.E. Koteen, A.B. Smith, R. Watson, J. Harte and R.B. Norgaard. 2008. The debt of nations and the distribution of ecological impacts from human activities. Proceedings of the National Academy of Sciences 105(5): 1768-1773.

Temper, L., I. Yánez, K. Sharife, G. Ojo, J. Martínez-Alier, CANA, M. Combes, K. Cornelissen, H. Lerkelund, M. Louw, E. Martínez, J. Minnaar, P. Molina, D. Murcia, T. Oriola, A. Osuoka, M.M. Pérez, T. Roa Avendaño, L. Urkidi, M. Valdés, N. Wadzah and S. Wykes. 2013. Towards a post-oil civilization: Yasunization and other initiatives to leave fossil fuels in the soil. EJOLT Report No. 6.

Third World Network [TWN]. 2009. Repay the climate debt: a just and effective outcome for Copenhagen. Penang: TWN.

Torras, M. 2003. An ecological footprint approach to external debt relief. World Development 31: 2161-2171.

United Nations Development Program [UNDP], 2007. Human development report 2007/2008: fighting climate change. human solidarity in a divided world. New York: UNDP.

United Nations Framework Convention on Climate Change [UNFCCC]. 2009. Commitments for Annex 1 Parties under paragraph 1(b)(i) of the Bali Action Plan: Evaluating developed countries' historical climate debt to developing countries. Submission by the Republic of Bolivia to AWG-LCA. Http://unfccc.int/resource/docs/2009/awglca 6/eng/misc04p01.pdf

UNFCCC. 2010. FCCC/AWGLCA/2010/MISC.2. Additional views on which the chair may draw in preparing text to facilitate negotiations among parties. Submissions from Parties. Bonn: UNFCCC. http://unfccc.int/resource/docs/2010/awglca10/eng/misc02.pdf

Vallejo, M.C. 2010. Biophysical structure of the Ecuadorian economy, foreign trade, and policy implications. Ecological Economics 70 (2): 159-169.

Wallerstein, I. 2004. World-systems analysis, an introduction. Durham: Duke University Press.

Warlenius, R. 2012. Calculating climate debt: a proposal. Paper submitted to ISEE 2012. Lund University : Department of Human Ecology.

Warlenius, R. 2016. Core and periphery in the early modern world system. a time-space appropriation assessment. In Jarrick, A., J. Myrdal and M. Wallenberg Bondesson (eds.). Methods in global history. a critical approach. Lund: Nordic Academic Press. Pp. 185-225.

Warlenius, R., G. Pierce and V. Ramasar. 2015. Reversing the arrow of arrears: The concept of 'ecological debt' and its value for environmental justice. Global Environmental Change 30: 21-30.

Warlenius, R., G. Pierce, V. Ramasar, E. Quistorp, J. Martínez-Alier, L. Rijnhout and I. Yanez. 2015. Ecological debt: history, meaning and relevance for environmental justice. EJOLT Report No. 18.

Yang Yu, K. Feng and K. Hubacek. 2014. China's unequal ecological exchange. Ecological Indicators 47: 156-163. 